\title{
Psychiatric Disorders in Lumbar Stenosis with Chronic Pain and Their Effects on Lumbar Stenosis Surgery
}

\author{
Kronik Ağrılı Lomber Stenoza Eșlik Eden Psikiyatrik Hastalıklar ve Lomber Stenoz Cerrahisine Etkileri
}

\author{
Șeyho Cem Yücetaș', Yelda Yenilmez², Can Hakan Yıldırım', Nergiz Hüseyinoğlư ${ }^{3}$, Yusuf Ehi ${ }^{3}$, Serhat Tunç², \\ Kadir Yıldırım', Necati Üçler ${ }^{4}$ \\ ${ }^{1}$ Department of Neurosurgery, Kafkas University, Kars, Turkey; ${ }^{2}$ Department of Psychiatry, Kafkas University, Kars, Turkey; \\ ${ }^{3}$ Department of Neurology, Kafkas University, Kars, Turkey; ${ }^{4}$ Department of Neurosurgery, Adryaman University, Adiyaman, Turkey
}

\begin{abstract}
AIM: Lumbar stenosis is a painful disorder frequently observed in advanced ages. Pain is a complaint that has significant consequences to quality of life. In this study, it was analyzed whether there are any comorbid psychiatric disorders in patients with lumbar stenosis and the variances in postoperative Visual Analogue Scale scores of these patients.

METHODS: Eighty patients who were evaluated and operated by the Department of Neurosurgery between December 2012 and April 2013 were subject to retrospective analysis. All patients were preoperatively consulted to a psychiatrist. The psychiatrist administered the SCID-I/CV (Structured clinical interview for DSM-IV axis I disorders, clinical version), Beck Depression Scale and Beck Anxiety Scale. Those patients with comorbid psychiatric disorders were given treatment with an SSRI (selective serotonin reuptake inhibitors) type antidepressant and regular follow-ups were made. Visual Analogue Scale scores of patients with or without comorbid psychiatric disorder were compared in the preoperative term and the postoperative months 1 and 6 .
\end{abstract}

RESULTS: Out of 80 patients diagnosed with lumbar stenosis, 22 were detected with major depression, 8 with generalized anxiety disorder and 5 with somatization disorder. The median, minimum and maximum Visual Analogue Scale scores of lumbar stenosis patients without comorbid psychiatric disorders was 3.7 (3.2-4.2) in the postoperative month 1 and 3.3 (2.7-3.9) in the postoperative month 6. The median, minimum and maximum Visual Analogue Scale scores of 35 lumbar stenosis patients with comorbid psychiatric disorders was 5.8 (5.3-6.4) in the postoperative month 1 and 3.4 (2.5-4.0) 6 months after psychiatric treatment was initiated.

CONCLUSION: Our aim was to emphasize that the treatment of comorbid psychiatric disorders in patients operated for chronic pain lumbar stenosis increases postoperative success.

Key words: lumbar stenosis; chronic pain; psychiatric disorder

\section{ÖZET}

AMAÇ: Lomber stenoz ileri yașlarda sık görülen ağrılı bir sorundur. Ağrı, yașam kalitesini ciddi boyutta bozan bir șikayettir. Lomber stenozu olan hastalarda eșlik eden bir psikiyatrik bozukluk olup olmadığı ve bu hastaların postoperatif Visual Analog Scale skorları değișkenleri değerlendirildi.

YÖNTEM: Aralık 2012 - Nisan 2013 tarihleri arasında Beyin ve Sinir Cerrahisi tarafından değerlendirilen ve opere edilen 80 hasta retrospektif olarak incelendi. Tüm hastalar preop psikiyatri uzmanı ile konsülte edildi. Psikiyatri uzmanı tarafından hastalara SCID-I (Structured clinical interview for DSM-IV axis I disorders), Beck depresyon ölçeği ve Beck anksiyete ölçeği uygulandı. Psikiyatrik bozukluk eșlik eden hastalara psikiyatri uzmanı tarafından SSRI (Serotonin gerialım inhibitörü) grubu bir antidepresan bașlandı ve düzenli aralıklarla kontrolleri yapıldı. Psikiyatrik bozukluk eșlik eden ve etmeyen hastaların preoperatif ve postoperatif 1 ve 6 ay sonraki Visual Analog Scale skorları karșılaștırıldı.

BULGULAR: Lomber stenoz tanısı alan 80 hastanın 22'sinde majör depresyon, 8'inde yaygın anksiyete bozukluğu ve 5'inde somatizasyon bozukluğu tespit edildi. Eșlik eden bir psikiyatrik bozukluğu olmayan lomber stenozlu hastaların postop 1. ay medyan, minimum ve maksimum Visual Analogue Scale skoru değerleri 3,7 (3,2-4,2), 6. ay Visual Analogue Scale skoru değerleri 3,3 (2,7-3,9) olarak kaydedildi. Psikiyatrik bozukluğun eșlik ettiği 35 hastanın 1. ay med-yan, minimum ve maksimum Visual Analogue Scale skoru değerleri 5,8 (5,3-6,4), psikiyatrik tedavi bașladıktan 6 ay sonra 3,5 $(2,5-4,0)$ olarak kaydedildi.

SONUÇ: Kronik ağrılı lomber stenoz nedeni ile opere edilen hastalarda eșlik eden psikiyatrik bozukların tedavi edilmesinin postoperatif operasyon bașarısını arttırdığını vurgulamak istedik.

Anahtar kelimeler: lomber stenoz; kronik ağrl; psikiyatrik bozukluk 


\section{Introduction}

Chronic pain in lumbar stenosis is defined as persistent pain for more than 6 months ${ }^{1}$. In such cases, chronic pain becomes more of a syndrome than a finding and very often co-occurs with psychiatric diseases.

The pain might be a symptom for a psychiatric disorder or the physical disorder may cause a disorder in the mental situation of the individual ${ }^{2,3}$. The pain has physiological, psychological and psychosocial components and it is perceived as a subjective whole with the interaction of these components. Accordingly, a multidisciplinary approach to patients is required ${ }^{4}$.

Today, many scales are used in order to evaluate pain in such patients, the most common being Visual Analog Scale $(\mathrm{VAS})^{19}$. It is known that chronic pain due to lumbar stenosis has a generally negative effect on the psychological mood of the patient. These patients' treatment process is multidisciplinary, in that the patients undergo medical treatment and physiotherapy as well as conservative treatments. Those patients who do not benefit from these treatments are surgically operated.

\section{Method}

Eighty consecutive patients who were evaluated by the Department of Brain and Nerve Surgery and the Psychiatric Clinic of the Faculty of Medicine, Kafkas University between December 2012 and November 2013 and diagnosed with lumbar stenosis were included in the study. The study was approved by the local ethics committee and has therefore been performed in accordance with the ethical standards laid down in the 1964 Declaration of Helsinki and its later amendments. All patients gave their informed consent prior to their inclusion in the study.

Patients who had lumbar stenosis with clinic findings observed in lumbar stenosis such as at least 6 months of chronic pain, loss of strength and senses, claudicating, urinary and fecal incontinence and who underwent medical pain treatment for at least 6 months and physiotherapy at least once were included in the study.

Patients who were operated twice due to recurrence, patients diagnosed with polyneuropathy, infection, trauma and simple discectomy as well as patients with mental deficiency were not included in the study for homogentiy of all groups. All patients underwent at least 1 and at most 3 levels of laminectomy.
All patients were preoperatively consulted to a psychiatrist. The psychiatrist administered the SCID-I/ CV (Structured clinical interview for DSM-IV axis I disorders, clinical version), Beck Depression Scale and Beck Anxiety Scale.

\section{SCID-I}

(Structured Clinical Interview for DSM-IV Axis I Disorders)

It is a clinical interview scale developed and structured for diagnosing major SM-IV Axis I. Translation into Turkish and the reliability study were conducted by Çorapçığlu et al. ${ }^{5}$.

\section{Beck Anxiety Scale}

Created by Beck et al. $(1988)^{6}$. It is a self-evaluation scale used in order to determine the frequency of anxiety symptoms that individuals experience. It is a Likert scale in the range of $0-3$ consisting of 21 questions. Turkish validation and reliability were made by Ulusoy et al. $(1998)^{7}$.

\section{Beck Depression Scale}

This scale developed by Beck (1961) measures the risk of depression, the level of depressive symptoms and variations in severity in adults ${ }^{8}$. Turkish validation and reliability were conducted by Hisli (1989) ${ }^{9}$.

Those patients with comorbid psychiatric disorders were given treatment with an SSRI (selective serotonin reuptake inhibitors) type antidepressant and regular follow-ups were made. All patients underwent preoperative Magnetic Resonance Imaging (MRI) and some underwent Computerized Tomography (CT) (Fig. 1 and 2).

All patients' VAS scores in the preoperative week 1, postoperative week one and month six were measured and the values were recorded. All patients took Non Steroidal Anti-Inflammatory Drugs for pain relief. The scores of the groups in $1^{\text {st }}$ week $-1^{\text {st }}$ month and $1^{\text {st }}$ week $-6^{\text {th }}$ month were compared statistically.

\section{Statistical Analysis}

The analysis of data was made using SPSS for Windows 11.5 program. Kolmogorov-Smirnov test was used to find out whether the distribution of continuous and discrete random variables complied with normal distribution. Descriptive statistics were shown as \pm standard deviation or number of cases (\%). The significance of the difference between the groups in terms of average of age was shown by Student's $t$ test whereas the significance of the difference in terms of VAS levels was 


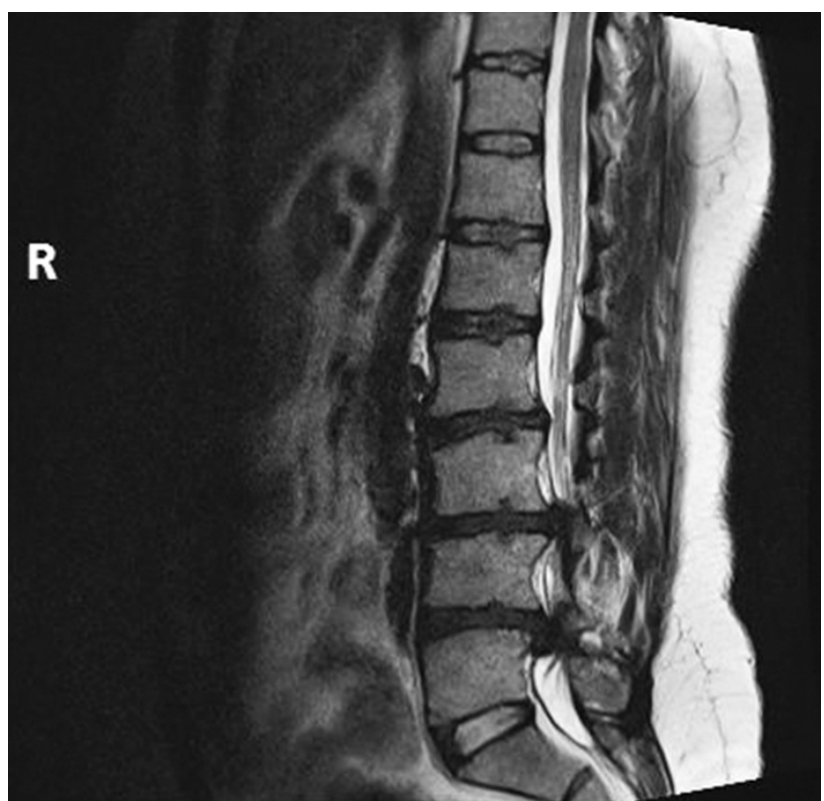

Figure 1. Magnetic resonance image showing the lumbar pathology.

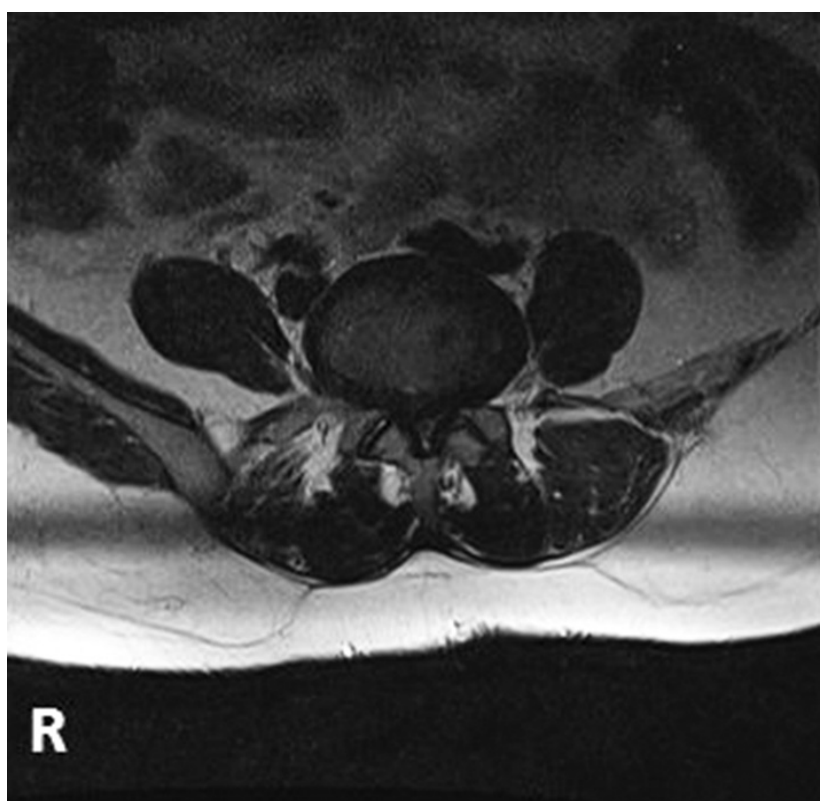

Figure 2. Computerized tomography image showing the lumbar pathology. examined through Mann Whitney U test. Pearson's chi-square test was used in order to show that the distribution of the gender groups was similar. Friedman test was used in order to examine as to whether there was a statistically significant difference in terms of VAS levels between monitoring times among the groups. When Friedman test statistical results were found significant, Wilcoxon Sign test was used to detect the monitoring time(s) that caused the difference. Unless otherwise indicated, $\mathrm{p}<0.05$ results were considered statistically significant. However, in all probable multiple comparisons, Bonferroni Correction was made in order to control Type I error.

\section{Results}

Fifty patients were female and 30 patients were male with an mean age of $54 \pm 8.33$. Forty five of the patients were not diagnosed with any comorbid psychiatric disorders. Out of the remaining 35 patients, 22 were diagnosed with major depression, 8 with generalized anxiety disorder and 5 with somatization disorder (Fig. 3 and 4 ).

There was a statistical difference found between the scores of preoperative $1^{\text {st }}$ week and postoperative $1^{\text {st }}$ month $(p<0.001)$. On the other hand, no significant difference was encountered between the scores of preoperative $1^{\text {st }}$ week and postoperative $6^{\text {th }}$ month $(\mathrm{p}=0.623)($ Table $1-3)$.

\section{Discussion}

Lumbar stenosis is is an illness caused by bone hypertrophy, ligamentous hypertrophy, disc protrusion or spondylolisthesis individually or together, which leads to the narrowing of the canal and foramina ${ }^{1}$. The etiology of lumbar spinal stenosis is divided into primary etiology and secondary etiology. The development of primary spinal stenosis is due to congenital anomalies or postnatal developmental disorders. As for the development of secondary (acquired) spinal stenosis, degenerative changes, local infections, trauma, metabolic diseases and surgical interventions are held responsible. The most common cause of lumbar spinal stenosis is a slow progressing degenerative process seen in the level of the last 3 lumbar vertebrae. Degenerative changes mostly affect the central spinal canal, foramens and lateral recess. As a result of these changes, narrowing in the anteroposterior and transverse diameters takes place and various clinic findings occur ${ }^{10,11}$. All cases in our study developed due to degeneration. The physiopathological changes due to lumbar stenosis were studied via clinical observations and on animal models. For example, Olmarker et al. explained spinal stenosis findings in animal models by the pressure of degenerative changes on the spinal nerves and impaired blood flow of the cauda equine ${ }^{12}$. The primary finding for patients with lumbar spinal stenosis is neurogenic claudication. 


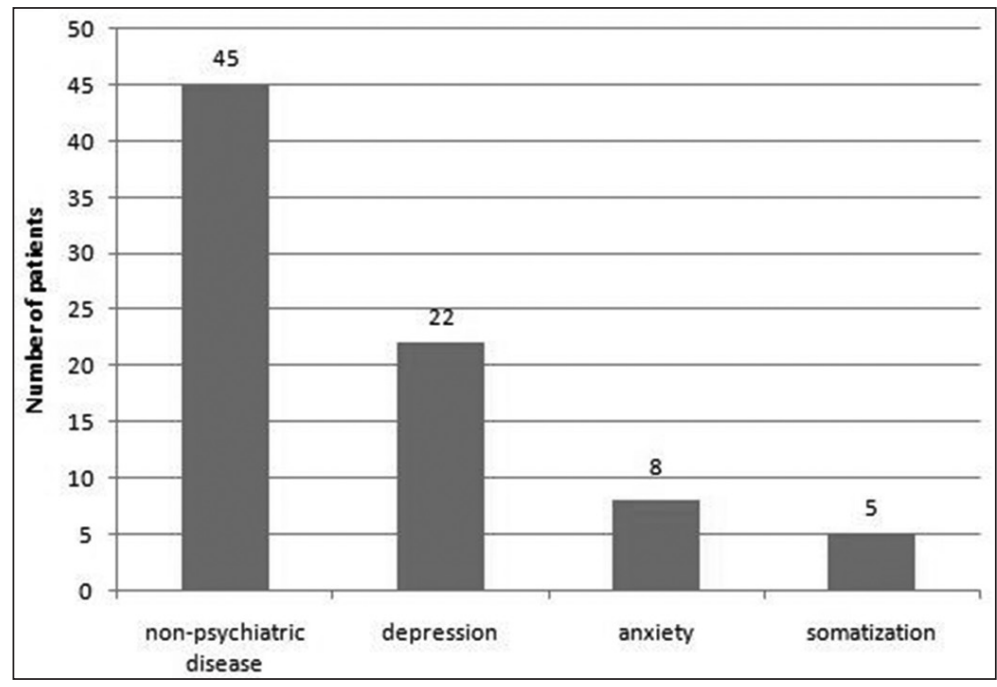

Figure 3. Patients' distribution according to psychiatric diseases.

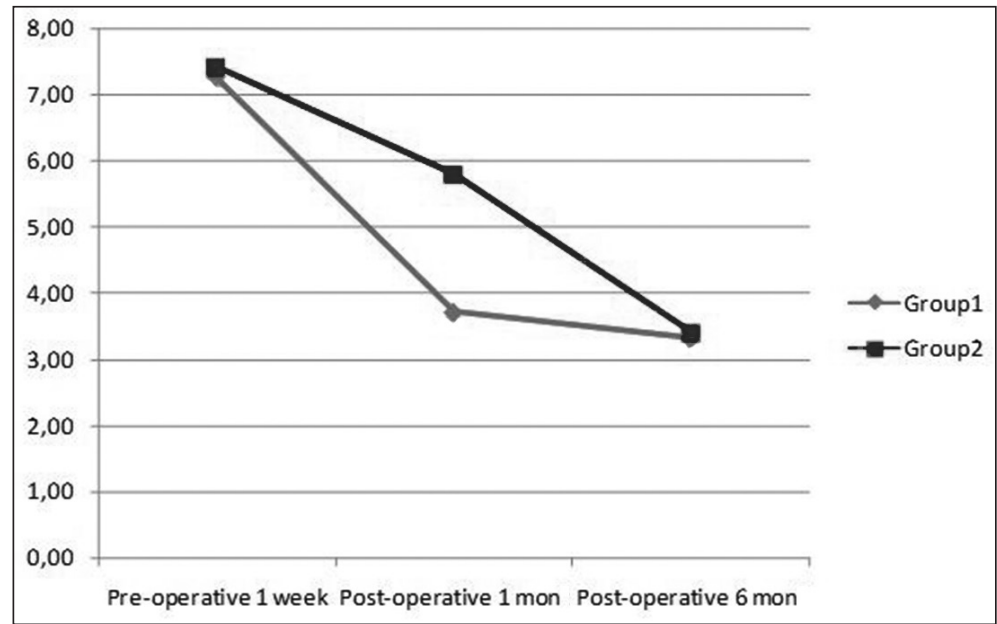

Figure 4. Pre-operative 1 week, post-operative 1 month, and post-operative 6 month scores.

Patients complain about back and leg pains, fatigue, topognosis and lack of strength. In addition to neurogenic claudication, these patients also have radicular pain. The findings are mostly bilateral and sometimes unilateral and increase by extension and decrease by flexion. Nocturnal leg cramps are very frequent. In addition, patients may experience neurogenic bladder problems. Neurological examinations of these patients are mostly normal; however, occasional mild loss of sensation and motor strength in the lower extremities are observed. Now and then, focal motor loss that conforms to stem distribution and positive results in stretching tests might be found on examination ${ }^{13,14}$. Our patients most frequently showed claudication, loss of sense and loss of strength, while only 3 patients had urinary incontinence and 1 patient had fecal incontinence.

The pain might be radicular or rudiment. Such patients often have comorbid chronic pain. The International Association for the Study of Pain (IASP) defines pain as an unpleasant sensory and emotional experience associated with actual or potential tissue damage. $98 \%$ of patients with pain were detected with an Axis 1 disorder whereas 37\% were detected with an Axis 2 disorder $^{15}$. In patients with chronic pain, the pain and the accompanying symptoms might lead to a decrease in functionality and physical capacity and at the same time cause symptoms such as depression, anxiety and a decrease in social relations, which may lead to impaired quality of life $e^{3,16,17}$. The most common psychiatric disorder that 
Table 1. Demographical characteristics of the cases according to groups

\begin{tabular}{lccc}
\hline Variables & Group $1(\mathrm{n}=4556.2 \%)$ & Group $2(\mathrm{n}=3543.8 \%)$ & $\mathrm{p}$-value \\
\hline Age (year) & $54.3 \pm 8.7$ & $52.4 \pm 7.8$ & $0.313^{\mathrm{a}}$ \\
Gender & & & $0.181^{\mathrm{b}}$ \\
Female & $31(68.9 \%)$ & $19(54.3 \%)$ & $16(45.7 \%)$ \\
Male & $14(31.1 \%)$ & & - \\
Psychiatric disorder & - & $22(62.9 \%)$ & - \\
Major depression & - & $8(22.8 \%)$ & - \\
Generalized anxiety & - & $5(14.3 \%)$ & - \\
Somatization & & & \\
\hline${ }^{\mathrm{a}}$ Student'st test. & & \\
\hline
\end{tabular}

Table 2. VAS levels of the cases according to groups

\begin{tabular}{|c|c|c|c|}
\hline Monitoring Times & Group 1 & Group 2 & $p$-value ${ }^{\dagger}$ \\
\hline Pre-op & $7.24 \pm 0.28^{a, b}$ & $7.38 \pm 0.37^{\mathrm{a}, \mathrm{b}}$ & 0.207 \\
\hline Post-op month 1 & $3.71 \pm 0.29^{a, c}$ & $5.81 \pm 0.31^{a, c}$ & $<0.001$ \\
\hline Post-op month 6 & $3.32 \pm 0.32^{b, c}$ & $3.42 \pm 0.34^{b, c}$ & 0.216 \\
\hline $\mathrm{p}$-value ${ }^{\ddagger}$ & $<0.001$ & $<0.001$ & \\
\hline \multicolumn{4}{|c|}{$\begin{array}{l}{ }^{+} \text {Comparisons for VAS levels in each monitoring time among the groups were considered statistically significant for results with } p<0.017 \text { according to Bonferroni Corrected Mann Whitney U testi. } \\
\text { F Comparisons among the groups in terms of VAS levels between monitoring times were considered statistically significant for results with } p<0.025 \text { according to Bonferroni Corrected Friedman test. } \\
\text { a Difference between pre-op and post-op month } 1 \text { statistically significant }(p<0.001) \text {. } \\
\text { b difference between pre-op and post-op month } 6 \text { statistically significant }(p<0.001) \text {. } \\
\text { c difference between post-op month } 1 \text { and post-op month } 6 \text { statistically significant }(p<0.001) \text {. }\end{array}$} \\
\hline
\end{tabular}

Table 3. Decrease in VAS levels according to monitoring times

\begin{tabular}{lccc}
\hline Change Times & Group 1 & Group 2 & $\mathrm{p}$-value \\
\hline Post-op month 1 - pre-op & $3.53 \pm 0.43$ & $1.57 \pm 0.46$ & $<0.001$ \\
Post-op month 6 - pre-op & $3.92 \pm 0.44$ & $3.96 \pm 0.41$ & 0.623 \\
Post-op month 6 - post-op month 1 & $0.39 \pm 0.37$ & $2.39 \pm 0.41$ & $<0.001$ \\
\hline${ }^{\dagger}$ p $<0.017$ results were considered statistically significant according to Bonferroni Corrected Mann Whitney U test. & &
\end{tabular}

accompanies pain is depression. The rate of depression in the general population is $5-8 \%$, whereas the rate of occurrence of depression in patients with chronic pain is $22-78 \%^{18}$.

In order to evaluate these patients' pain, various classifications are used such as VAS, Oswesty and SF-36 ${ }^{19}$. In this study, we evaluated all patients with VAS scores in preoperative week one and postoperative months one and six.

Previous studies have shown the existence of severe depressive symptoms in patients with lumbar stenosis ${ }^{20}$. Various tests are used in patients with chronic pain which are SCID-I (Structured Clinical Interview for the DSM-IV Axis I Disorders), Beck Anxiety Scale and Beck Depression Scale ${ }^{7-9}$. Sinikallio et al. observed that
$20 \%$ of the patients with lumbar stenosis in their study had depression ${ }^{21}$. In our study, our psychiatrist detected major depression in 22 patients, generalized anxiety disorder in 8 patients and somatisation disorder in 5 patients. In the light of these findings, we may conclude that as a result of the pain due to lumbar stenosis, the risk of development of psychiatric disorders increases.

These patients are given medical and surgical treatment. Since these patients often have comorbid depression, the participation of a psychiatrist in the treatment is a necessity $^{16}$. Diagnosis for lumbar spinal stenosis is effected clinically, radiologically and electrophysiologically. Verbiest et al. defined the spinal canal diameter as 10 to $12 \mathrm{~mm}$ for relative spinal stenosis and defined diameters under $10 \mathrm{~mm}$ as absolute stenosis ${ }^{22}$. In this study, notch 
and canal widths were measured in all patients by preoperative MRI and CT and those patients with canal stenosis were evaluated.

As treatment alternatives for spinal stenosis patients, conservative treatment (medications, physiotherapy and exercise), injection treatment and surgical methods are recommended. For medical treatment, analgesics, myorelaxants, antidepressants, antiepileptics, intranasal and subcutaneous calcitonin are recommended. In addition, patients may be given interlaminal epidural and foraminal corticosteroid and bupivacaine injections. In this study, the patients underwent at least 6 months of medical pain treatment and 1 month of physiotherapy. According to the results of the Sport study, serious complications and death are rarely observed after surgical interventions in lumbar spinal stenosis ${ }^{23}$. Aalto et al. evaluated the results of 21 studies and concluded that depression, cardiovascular disorders, gait disturbances and scoliosis may lead to bad subjective postoperative results. Lack of gait disturbance, depression or anxiety, additional diseases or distinct spinal stenosis as well as presence of financial welfare are advantageous prognostic indicators ${ }^{24}$.

As for surgical methods, decompressive laminectomy, interspinous decompression and bilateral laminectomy are used. The most beneficial method in surgery is wide laminectomy ${ }^{25,26}$. All patients in this study underwent total laminectomy thereby releasing the pressure on the cord by the decompression method.

\section{Conclusion}

Our aim is to emphasize the fact that chronic pain that accompanies lumbar stenosis increases the occurrence of psychiatric disorders in such patients and the preoperative diagnosis of these disorders and initiation of a multidisciplinary treatment increases postoperative success.

\section{References}

1. Takahashi N, Kikuchi S, Yabuki S, Otani K, Konno S. Diagnostic value of the lumbar extension-loading test in patients with lumbar spinal stenosis: a cross-sectional study. BMC Musculoskelet Disord 2014;31:15:259.

2. Kara H, Abay E. [Psychiatric approach to chronic pain]. Anadolu Psikiyatri Dergisi 2000;1:89-99.

3. Gonzales VA, Martelli MF, Baker JM. Psychological assessment of persons with chronic pain. NeuroRehabilitation 2000;14:69-83.
4. Özkan S. [Psychiatric and psychosocial aspects of pain]. Psikiyatrik Tip Konsültasyon-Liyezon Psikiyatrisi, Istanbul 1993;21-24.

5. Corapcioglu A, Aydemir Ö, Yildiz M, Esen A, Köroğlu E. Structured clinical interview for DSM-IV axis I disordersclinical version (SCID-I/CV) in Turkish: Study of reliability. İlaç ve Tedavi Derg 1999;12:233-6.

6. Beck AT, Epstein N, Brown G, Steer RA. An inventory for measuring clinical anxiety: Psychometric properties. J Consult Clin Psychol 1988;56:893-897.

7. Ulusoy M, Şahin N, Erkman H. Turkish Version of The Beck Anxiety Inventory: psychometric Properties. J Cognitive Psychotherapy: Int Quaterly 1998;12:28-35.

8. Beck AT, Ward CH, Mendelson M. An inventory for measuring depression. Arch Gen Psychiatry 1961;4:561-571.

9. Hisli N. [Beck Depression Inventory for university students on the validity and reliability]. Psikoloji Dergisi 1989;7:3-13.

10. Ciricillo SF, Weinstein PR. Lumbar spinal stenosis. West J Med 1993; 158:171-177.

11. Amundsen T, Weber H, Lilleås F, Nordal HJ, Abdelnoor M, Magnaes B. Lumbar spinal stenosis. Clinical and radiologic features. Spine 1995;15:1178-1186.

12. Olmarker K, Rydevik B, Hansson T, Holm S. Compressioninduced changes of the nutritional supply to the porcine cauda equina. J Spinal Disord 1990;3:25-29.

13. Matsumoto M, Watanabe $\mathrm{K}$, Tsuji $\mathrm{T}$, Ishii $\mathrm{K}$, Takaishi $\mathrm{H}$, Nakamura $\mathrm{M}$ at al. Nocturnal leg cramps: a common complaint in patients with lumbar spinal canal stenosis. Spine Phila Pa 2009;1;34: E189-94.

14. Inui Y, Doita M, Ouchi K, Tsukuda M, Fujita N, Kurosaka M. Clinical and radiologic features of lumbar spinal stenosis and discherniation with neuropathic bladder. Spine Phila Pa 2004;29:869-873.

15. Reich J, Tupin JP, Abramowitz SI. Psychiatric diagnosis of chronic pain patients. Am J Psychiatry 1983;140:1495-1498.

16. Deardorf W, Rubin H, Scott D. Comprehensive multi disciplinary treatment of chronic pain. Pain 1991;45:35-44.

17. Kaptan H, Yalçın ES, Kasımcan O. Correlation of low back pain caused by lumbar spinal stenosis and depression in women: a clinical study. Arch Orthop Trauma Surg 2012;132:963-967.

18. Haythornthwaite JA, Sieber WJ, Kerns RD. Depression and the chronic pain experience. Pain 1991;46:177-184.

19. Aoki Y, Sugiura S, Nakagawa K, Nakajima A, Takahashi H, Ohtori $S$ at al. Evaluation of nonspecific low back pain using a new detailed visual analogue scale for patients in motion, standing and sitting: characterizing non spesicific low back pain in elderly patient. Pain Res Treat 2012;680496.

20. Yabuki S, Fukumori N, Takegami M, Onishi Y, Otani K, Sekiguchi $\mathrm{M}$ et al. Prevalence of lumbar spinal stenosis, using the diagnostic support tool and correlated factors in Japan: a population-based study. J Orthop Sci 2013;18:901.

21. Sinikallio S, Aalto T, Airaksinen O, Herno A, Kroger H, Savolainen $S$ at al. Depression and associated factors in patients with lumbar spinal stenosis. Disabil Rehabil 2006;28:415-22. 
22. Verbiest H. Pathomorphologic aspects of developmental lumbar stenosis. Orthop Clin North Am 1975;6:177-196.

23. Gibson JN, Waddell G. Surgery for degenerative lumbar spondylosis. Cochrane Database Syst Rev 2005; 19: CD001352.

24. Aalto TJ, Malmivaara A, Kovacs F, Herno A, Alen M, Salmi L et al. Preoperative predictors for postoperative clinical outcome in lumbar spinal stenosis: systematic review. Spine Phila $\mathrm{Pa}$ 2006;15;31: E648-63.
25. Deer TR, Kim CK, Bowman RG 2nd, Ranson MT, Yee BS. Study of percutaneous lumbar decompression and treatment algorithm for patients suffering from neurogenic claudication. Pain Physician 2012;15:451-460.

26. Manchikanti L, Cash KA, McManusCD, Pampati V. Assessment of effectiveness of percutaneous adhesiolysis in managing chronic low back pain secondary to lumbar central spinal canal stenosis. Int J Med Sci 2013;10:50-59. 